original founders of the Boy Scouts of America. He served as a guide for the Grand Duke Alexis of Russia. There were over 800 books written about him with many diverse stories and legends about his western exploits. He authored many books, including: "Story of Wild West" and "Camp Fire Chats" (1888) and "True Tales of the Plains" (1908).

Colonel William Fredrick Cody died Jan. 10, 1917, and is buried on Look Out Mountain near Golden, Colo. For many generations, he has been known as Buffalo Bill-Prince of the Plains. Many streets, dams, towns, museum and villages are named for Buffalo Bill, but his greatest monument lives on in the minds of the young of all ages that worship Buffalo Bill as the American Folk Hero that he is!

\title{
THE CIVIL WAR DIARY OF SGT. LEVI L. HOAG
}

\section{Edited by Edwin C. Bearss}

The officers and men who had enlisted in the 24th Iowa Infantry were ordered into quarter by Gov. Samuel J. Kirkwood in the period between Aug. 16 and 28, 1862. The designated rendezvous was Camp Strong, located at Muscatine, Iowa. ${ }^{1}$

One of the men of the 24th Iowa recalled:

We arrived in Muscatine at night and took the only two barracks that were completed. Company A had been there several days and had mostly built their own barrack. In a week the other companies had arrived ... We certainly had a right to be called a green regiment for I have been able to count but six out of the 982 men that when they enlisted knew how to form a company. As one company disembarked from the cars, got off their traps and the train moved on the captain said: "Gentlemen, get in two rows side by side", and when they had got, he said "Now follow me into camp", and he started off like a bellwether and they followed him to camp. $^{2}$

The ten companies which would constitute the 24th lowa

${ }^{1}$ Roster and Record of Iowa Soldiers in the War of the Rebellion-Together with Historical Sketches of Volunteer Organizations, 1861-1866, Vol. III (Des Moines, 1909), 781.

${ }^{2}$ Tipton Advertiser, August 29, 1902. 
were mustered into Federal service on Sept. 18, 1862 by Capt. Henry B. Hendershott. The regiment remained at Camp Strong until Oct. 19. ${ }^{3}$

If the "awkward and ridiculous things" that transpired in the 54 days the regiment was at Camp Strong could be printed, it would "make quite a book".

Sgt. Elam C. Miles of Co. E, one of the soldiers observed, was:

... the most polite man under all circumstances I ever knew. When he first came into camp his order in forming the company was, "Gentlemen, please form in two ranks. Will Captain (Leander) Clark's company please to right dress." And when we drew our guns and he took the company out for drill, after halting them on the parade grounds, he said:

"Gentlemen, we are now about to go through a series of evolutions known as the manual of arms, and the beauty and usefulness of these movements will depend in a large degree upon the celerity and unity." And although army life soiled and wore out his uniform, it never wore out his politeness. ${ }^{4}$

On Oct. 19, the soldiers marched to the levee and embarked on steamboats. Proceeding down the Mississippi River, the regiment landed at Helena, Ark., nine days later. The Iowans went into camp south of the town and were assigned to the brigade commanded by Col. George F. McGinnis of the 11th Indiana. During the trip down the Mississippi, many of the soldiers had sickened; the unhealthy locality in which the regiment was now encamped added greatly to the sick list. "The privations and hardships endured by the 24th Iowa, while at Helena and when engaged in the several expeditions in which it participated during the winter of 1862-3, were the most severe in its history."

Nov. 17 found the regiment back aboard transports. The Iowans participated in the expedition which Brig. Gen. Alvin P. Hovey led to the mouth of the White River. It was Hovey's plan to ascend the White River and capture the Post of Arkansas. However, low water in the White River frustrated Hovey's plans and he was forced to return to Helena.

Following their return from the White River, the Iowans remained in their camp only a few days. On Nov. 27, the

${ }^{3}$ Roster and Record of Iowa Soldiers, III, 781.

${ }^{4}$ Tipton Advertiser, August 29, 1902.

${ }^{5}$ Roster and Record of Iowa Soldiers, III, 781. 
Iowans, along with a number of other Union units, crossed the Mississippi River and landed at Delta, Miss. According to the plans worked out by the Union leaders, Gen. Hovey was to lead his command eastward and capture Grenada. The Union force, however, bogged down in the upper Delta and was unable to reach its objective. The 24th Iowa, along with the other units of the raiding force, returned to Helena on Dec. 7. Dr. Carhart, of Marion, stated, "That trip cost the army 1,000 men in dead and disabled."

During the second week of January 1863, the 24th Iowa, along with other Union units, accompanied Brig. Gen. Willis A. Gorman when he led a force up the White River to St. Charles, Ark. Gorman's thrust was made in support of the Union attack on the Post of Arkansas. While no large bodies of Confederate troops were encountered on any of these expeditions, the troops suffered almost unendurable hardships from exposure to the elements. The fatalities which resulted were as great as those sustained in many of the hard-fought battles in which the regiment subsequently participated. The veterans always remembered that winter campaign "as the most discouraging of the many through which they passed in their long period of service." Upon its return from the White River expedition, the regiment found its camp flooded. The troops were accordingly forced to move to higher ground. ${ }^{7}$

The 24th Iowa again left Helena on Feb. 15-their mission, to help open Yazoo Pass for navigation. This duty, while arduous, gave the men active employment and relieved them from the distressing effects of witnessing the daily depletion of their ranks from disease while lying idle in camp. Upon the Iowans' return from the Yazoo Pass, the regiment was assigned to the XIII Army Corps. ${ }^{8}$

Sgt. Levi L. Hoag, a resident of Cedar County, was 29 years old at the time of his enrollment on Aug. 15, 1862. He was an average soldier of the line. His knowledge and interest lay more in the sort of camp site and the rations he drew than in the overall strategy of the campaign.

${ }^{6}$ Ibid.; Tipton Advertiser, August 29, 1902.

${ }^{7}$ Roster and Record of Iowa Soldiers, III, 782.

${ }^{8}$ Ibid. 
Hoag discussed the things around him-the weather, the length of the march, the friends he saw, and the forage his company found. Cannon fire, other than in his immediate vicinity, might be mentioned casually; but there is no speculation on his part as to whose cannons were fired. The sergeant's education was average. He evidently believed in doing his part of the fighting and not worrying about other commands. ${ }^{9}$

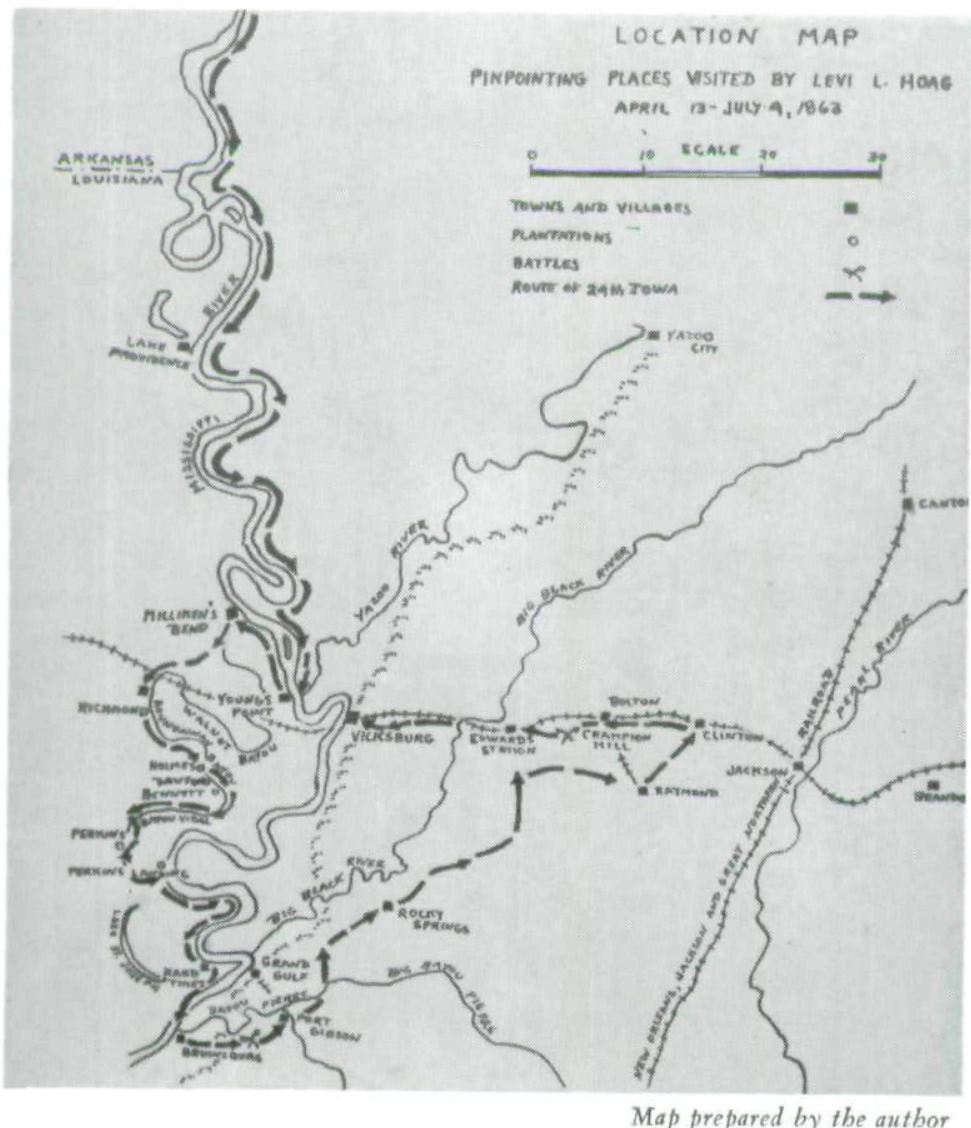

Map Pinpointing Places Visited by Sgt. Hoag

Levi Hoag was born in Greene County, N. Y., on April 10, 1831. At the time of the firing on Fort Sumter, Hoag was farming in Cedar County, Iowa. He enlisted at Tipton for three years' service in Company $\mathrm{H}$, 24th Iowa, on Aug. 15, 1862. At this time, Hoag was 31 years old, 5 feet 4 inches tall, with brown hair.

${ }^{9}$ Ibid., 835. 


\section{The Diary of Sgt. Hoag}

April 1st. Wednesday. Pleasant. We took the tops off all our tents to let them dry inside. Battalion drill, dress parade.

2nd, Thursday. Pleasant. Drill in the forenoon. Reported marching orders soon. Capt. [Silas D.] Johnson putting up a shanty to live in. ${ }^{1}$ Drill in the afternoon. Dress parade in the evening.

3rd, Friday. Pleasant but windy. I was on guard. Company drill in the forenoon. Battalion drill in the afternoon. Dress parade.

4th, Saturday. Pleasant. Brigade drill in the afternoon. I fixed up a bunk for Jim Ashton and me to sleep on. ${ }^{2}$ Dress parade.

5th, Sunday. Pleasant. Inspection of arms and knapsacks in the morning. We had regimental inspection in the afternoon by Col. [Peter] Kinney. ${ }^{3}$ [Major] Gen. [Benjamin M.] Prentiss and others made speeches at the fort in the afternoon. 60 men detailed from the 24th [Iowa]. ${ }^{4}$ Dress parade.

6th, Monday. Pleasant. We signed the pay roll in the forenoon. In the afternoon we were formed in line and marched over to the fort, where we heard some splendid speeches. First [Brig.] Gen. [Alvin P.] Hovey spoke a few words, then Adjt. Gen. [Lorenzo] Thomas from Washington City was introduced on the stand where he made a short

${ }^{1}$ Silas D. Johnson hailed from Tipton. He had been commissioned captain of Co. C on Aug. 6, 1862. Roster and Record of Iowa Soldiers, III, 844. 1862.

${ }^{2}$ James E. Ashton of Tipton had enlisted in the 24th Iowa on Aug. 11,

${ }^{3}$ Col. Peter Kinney of the 56th Ohio commanded the brigade to which the 24th Iowa was assigned. On April 9, Col. Kinney resigned his commission and returned to Ohio. Following Kinney's departure, Col. James R. Slack of the 47th Indiana assumed command of the brigade. Official Roster of the Soldiers of the State of Ohio in the War of the Rebellion. 1861-1866, Vol. V (Akron, 1887), 85; Frederick H. Dyer, A Compendium of the War of the Rebellion (Des Moines, 1908), 494.

${ }^{4} \mathrm{Gen}$. Prentiss was in charge of the District of Eastern Arkansas, the administrative command to which the 24th Iowa was assigned at this stage of the conflict. The fort at Helena was known as Fort Curtis. $O$. R., Series I, Vol. XXIV, pt. III, 163; Dyer, Compendium of the War of the Rebellion, 494. 
speech on the policy of arming the negros. He was followed by Gen. Prentiss, who made an able speech. Then Gen. Hovey was again called upon. He was followed by [Maj.] Gen. [Cadwallader C.] Washburn. He was followed by Col. [Robert H.] Cameron of the 34th Indiana regiment. He was followed by the Col. of the 29th Wisconsin, then the Provost Marshal. Then Maj. Gen. Prentiss made a few remarks, followed by Adjt. Gen. Thomas, when the meeting closed with three hearty cheers for the Union. ${ }^{5}$

7th, Tuesday. Pleasant. Company drill in the forenoon, brigade drill in the afternoon. Gen. Hovey announced to us that in all probability we would meet the enemy in a few short days at the fartherest [sic], so we expect to leave here very soon. Dress parade.

8th, Wednesday. Pleasant. Company and brigade drill. Gen. Hovey sent word to Col. [Eber C.] Byam to have his men ready in two days. ${ }^{6}$ Dress parade.

9th, Thursday. Pleasant. Making preparations for a move, we expect to go tomorrow.

10th, Friday. Pleasant. We were mustered for pay and were paid four months pay. I sent $\$ 50$ to B. F. Gue at Davenport by express. The rest of the boys are sending money home. I wrote a letter to Father, got one from Nan. I sold my watch to [William H.] Southern for $\$ 10.00$. $^{7}$

11th, Saturday. Rainy. We had orders in the morning to have our things ready to leave camp at 4 o'clock. We were ready at the time and marched to town and went on Board

${ }^{5}$ Gen. Hovey led the 12th Division, XIII Army Corps. The 12th Division was organized in two brigades-the first commanded by Brig. Gen. George F. McGinnis, and the second headed by Col. Slack. Gen. Washburn had recently been placed in charge of all the Union cavalry operating in West Tennessee. At this time, Col. Charles R. Gill led the 29th Wisconsin. O. R., Series I, Vol. XXIV, pt. III, 164, 251.

The Federal government had made a radical change in its policy in regard to the use of Negro soldiers. Negroes would be encouraged to enlist in the Union army. Gen. Thomas had been sent to the Mississippi Valley by the Washington authorities to rally support for this policy. Bruce Catton, Grant Moves South (Boston, 1960), 401-403.

${ }^{6}$ Eber C. Byam, a resident of Mt. Vernon, had been appointed colonel of the 24th Iowa on Aug. 7, 1862. Roster and Record of Iowa Soldiers,
III, 795.

${ }^{7}$ A resident of Tipton, William H. Southern had enlisted in the 24th Iowa on July 24,1862 . Ibid., 880. 
the steamer "Frank Steel," where we stayed at the wharf till morning. Rained all night.

12th, Sunday. Pleasant. We started at sunrise down the river, went six miles and landed where there was a large fleet camped. ${ }^{8}$ We stayed there till about noon when we again started down the river, the whole fleet. We had preaching on our boat by Capt. [Jacob B.] Casebeer. $^{9}$

We passed the mouth of the White River about 5 o'clock P. M. There were two gunboats there to guard the river. We passed the Arkansas River and Napoleon about 6 o'clock. Napoleon is quite a pretty place but nearly deserted, and is nearly surrounded by water. We stopped once in the night. We saw some suspicious looking boats, thought they were Rebel boats, but they proved to be all right. We stopped near Greenville where we stayed till morning. A pretty little place.

13th, Monday. Rainy. We started down the river at daylight. Saw some pretty places along the river. We passed Lake Providence about noon. Saw the 11th [Iowa] regiment within speaking distance, but could not land to see them. I have not been so much disappointed since I have been in the service. ${ }^{10}$ We stopped within ten rods of the shore, but could not land. Capt. Johnson went off in a little boat and was left there.

We stopped some time at the upper landing at Young's Point. They took the mules off thinking we were going to camp there, but brought them on board again to await further orders. The country is low and level and very wet at the present time, but a very pretty tract of country. We stayed on board all night. Rained hard.

\footnotetext{
${ }^{\mathbf{s}}$ After leaving Helena, the convoy with Hovey's troops aboard moved down the river to the mouth of Yazoo Pass. Here, the vessels rendezvoused with the transports which carried Brig. Gen. Isaac F. Quinby's troops. Quinby's division had just returned to Yazoo Pass, after failing to capture Fort Pemberton. O. R., Series I, Vol. XXIV, pt. I, 418-419; History of the 46th Regiment Indiana Volunteer Infantry (Logansport, 1898), 53-54.

${ }^{9} \mathrm{Jacob}$ B. Casebeer of Iowa City was appointed a captain in the 24th Iowa on Aug. 9, 1862. At this time, Casebeer commanded Co. D. Roster and Record of Iowa Soldiers, III, 810.

${ }^{10}$ The 11th Iowa was assigned to the XVII Army Corps. Co. C., 24th Iowa and Co. E, 11th Iowa had been raised in Cedar County.
} 
14th, Tuesday. Pleasant. We started about daylight, went up the river about three miles and landed at Milliken's Bend. We went on shore and went in camp about a quarter of a mile. The prettiest place I have seen in the south, a large beautiful house surrounded by beautiful hedges of sweet brier and a grove of beautiful trees, upon the whole it is a very nice place to camp in. We got our tents nicely put up when an order came to pack up, put the things we could not carry in the boat and be ready for a march by 3 o'clock in the morning. ${ }^{11}$ Too bad as we are in such a pretty place.

15th, Wednesday. Pleasant. We did not march as expected yesterday, but expect to go tomorrow. We put what we could not carry on a boat, preparing for a start. There have a great many troops gone ahead. ${ }^{12}$

16th, Thursday. Pleasant. We started about nine o'clock on our march. We passed through a beautiful country, corn up from 2 to 6 inches. We crossed the railroad that went to Richmond. ${ }^{13}$ We camped at Richmond all night. I was sick with the sick headache but slept very well however.

17th, Friday. Pleasant. We started early on our march, stopped often; a good many sore feet; some gave out on the way. We passed through a splendid country. Corn is the only crop they are raising here, and no one to tend that now, as the

\footnotetext{
${ }^{11}$ Hovey's troops loaded their surplus gear aboard the steamers Cheeseman and Curlew. History of the 46th Indiana, 54.

${ }^{12}$ On March 29, Gen. Grant had issued orders for Gen. McClernand to open communications between Milliken's Bend and New Carthage. Two days later, McClernand sent a combat team led by Col. Thomas W. Bennett to reconnoiter this route. Pushing forward, Bennett's command discovered that there was a feasible road running along the natural levee which bounded Rounday Bayou on the west. By utilizing this road, the Army of the Tennessee would be able to march to Pointe Clear plantation, which was two miles north of New Carthage, without difficulty. When he was notified of this, Grant directed McClernand to move his XIII Corps to the advance staging area. By the time Hovey's division reached Milliken's Bend, McClernand's three other divisions had either reached or were well on their way to Pointe Clear. O.R. Series I, Vol. XXIV, pt. I, 30, 46, 490-491, 495-496; O. R., Series I, Vol. XXIV, pt. III, 197; George Cooke, The 21st Regiment of Iowa Volunteer Infantry (Milwaukee, 1891), 50.

${ }^{13}$ The railroad which the soldiers crossed was the Vicksburg, Shreveport, and Texas. At this stage of the conflict, the section of the railroad linking Delhi with De Soto was not operating. Richmond was the seat of government for Madison Parish.
} 
Rebs all fled before the approach of our troops. We have on this march over 20 regiments from Iowa. ${ }^{14}$ At 10 o'clock we stopped to rest in a beautiful grove, the soldiers lying on their knapsacks to rest. We expect a brush with the Rebs soon. We went three miles further, stopped for dinner and stayed there the rest of the day and night. We stretched our oil cloth blankets on four stakes for shelter. The head of our army had a brush with the Rebs, as we heard cannonading ahead. ${ }^{15}$ We had plenty of cotton for beds to sleep on. We passed Holmes' plantation. ${ }^{16}$

18th, Sat. Pleasant. Inspection of arms through the whole brigade. Some were condemned and inspected again at 1 o'clock. [William H.] Hunnicutt was detached to the pioneer corps. ${ }^{17}$ Cannonading ahead. Rained.

19th, Sunday. Pleasant. Dick Roberdee detached to [Battery A] 1st Mo. Light Artillery. ${ }^{18}$ Inspection of arms at 9 o'clock. 2 o'clock had orders to pull up and start. Left Dawson's plantation, went one mile and camped on Bennett's plan-

${ }^{14}$ Corp. Hoag apparently let his enthusiasm run away with him. At this time, only the XIII Corps had taken up the march for the New Carthage area. Instead of 20 , there were only five Iowa Infantry Regiments (the 21st, 22d, 23d, 24th and 28th) assigned to McClernand's XIII Corps. O. R., Series I, Vol. XXIV, pt. III, 250-251.

${ }^{15}$ Although Corp. Hoag fails to mention it, eight Union gunboats and two transports succeeded in passing the Vicksburg batteries on the night of April 16. This was a decisive event. With these vessels, Grant now had the necessary means to ferry his army across the Mississippi south of Vicksburg. On the afternoon of the 17th, two of the gunboats (the Lafaystte and the Tuscumbia) had shelled the woods south of Ione plantation. A small Confederate force led by Maj. Isaac F. Harrison was holding this area. Harrison's troopers hoped to delay McClernand's advance down the levee from New Carthage. Following the bombardment by the Union ironclads, Harrison's greyclads fell back to Lake St. Joseph. Official Records of the Union and Confederate Navies in the War of the Rebellion, Series I, Vol. 24, p. 704 (Cited hereafter as O. R. N.); Alfred T. Mahan, The Gulf and Inland Waters (New York, 1883), 155.

${ }^{16} \mathrm{Lt}$. Gen. Theophilus H. Holmes, the Confederate commander of the District of Arkansas, owned this plantation.

${ }^{17} \mathrm{~A}$ resident of Tipton, William H. Hunnicutt had enlisted in the 24th Iowa on Aug. 15, 1862. Roster and Record of Iowa Soldiers, III, 835.

${ }^{18}$ William R. Roberdee, a resident of Tipton, had enlisted in Co. C, 24th Iowa on Aug. 8, 1862. Battery A was one of the four artillery units attached to Hovey's division. Ibid., 873; O. R., Series I, Vol. XXIV, pt. III, 251. 
tation. The way the fences and buildings came down was a caution to Uncle Sam. Roll call six times a day.

20th, Monday. Pleasant. Roll call at 6 o'clock. Drill from 7 to 9 o'clock, roll call at 9 o'clock, dinner and roll call at 12 o'clock. Battalion drill from to 2 to 4 o'clock. Roll call at 3 o'clock in the middle of drill hours. Dress parade and roll call six o'clock. Roll call at 9 o'clock.

21st, Tuesday. Rainy. Orderly's call beat at 3 o'clock in the morning and orders came for us to march at 6 o'clock. We marched 8 miles, stopped for dinner, then went two miles further and went in camp for the night. Rained very hard after we got in camp, mud and water about a foot deep. The fences and buildings came down in a hurry. Hogs, cattle, molasses, etc., had to suffer. They are building a bridge across the bayou [Bayou Vidal] for the troops to cross on. We are on Perkins' plantation. ${ }^{19}$

22nd, Wed. Pleasant. We got up to roll call and eat our breakfast in the mud. The pioneer corps are tearing down houses to build the bridge of. The mud is drying fast today as it is warm.

23rd, Thursday. Pleasant. Cannonading in the direction of Vicksburg. A regiment of cavalry came in here today. They swam their horses across the bayou. One Lieut. and on Sergt. and one corporal were publicly reprimanded before the officers and men of the 24th Regiment by Col. Byam for stealing molasses and selling it to the men. Jim Ashton promoted to corporal. Dress parade.

${ }^{19} \mathrm{To}$ facilitate his advance from Pointe Clear to Hard Times Landing, McClernand ordered Hovey to move his division along the road which paralleled the west bank of Bayou Vidal. Hovey's troops encountered no difficulty in marching from Bennett's to Dunbar's plantation. At Dunbar's Hovey learned that a mile and one-half section of the road between Mill and Nigger Bayous was under water. Apparently, the natural levee was very low in this area. The water from the Mississippi which was pouring into Bayou Vidal through the crevasses in the levee near New Carthage escaped to the west at this point.

To avoid the flooded countryside west of Bayou Vidal, the Federal engineers decided to bridge the bayou. This bridge would be constrncted just above where Mill Bayou joined the large stream. Philip M. Thienel, "Bridges in the Vicksburg Campaign", The Military Engineer, Nov.-Dec. 1955; O. R., Series I, Vol. XXIV, pt. I, 126-127. 
24th, Friday. Pleasant. Company drill in forenoon. Battalion drill in afternoon. Dress parade. Still working at the bridge.

25th, Sat. Pleasant. Company drill in forenoon. Drew three days ration. Roll call seven times a day.

26th, Sunday. Rainy. Regimental inspection of arms at 9 o'clock. Marching orders to leave in the morning at 5 o'clock. Rained all night.

27th, Monday. Rainy. We started on our march at 7 o'clock. We crossed the Bayou and went slowly on as it was raining hard all the way. ${ }^{20}$ The roads were very bad; we had to stop often. About dark they put us through a double quick for 3 miles when we went in camp for the night on a field of Clover on Perkins' plantation. We got a mail about 12 o'clock in the night. I got 3 or 4 letters.

28th, Tuesday. Pleasant. We left the place about noon and marched about two miles to the Mississippi river, where we camped a short time then went on board the "Moderator." Started at midnight down the river.

29th, Wed. Pleasant. We were roused at 3 o'clock in the morning and were told to prepare to storm the forts at Grand Gulf in an hour, ${ }^{22}$ but the Gen. changed his mind and we did not make the charge. There is a large force here, besides seven gunboats. At 8 o'clock the gunboats opened fire on the forts and kept it up till about noon. They silenced all the guns but $3 .^{23}$

${ }^{20}$ Altogether, it had been necessary for the engineers and pioneers to build three bridges-two across Bayou Vidal, and one across a small slough on the east side of the bayou. It had taken Hovey's troops five days to complete the bridges and to cut the road down the east side of Bayou Vidal. Much of the work had been of the hardest kind; some of the soldiers having to labor up to their necks in the water. Diary, Lt. Col. William H. Raynor of the 56th Ohio (files, V. N. M. P.).

${ }^{21} \mathrm{On}$ the night of April 22, five transports succeeded in passing the Vicksburg batteries. The Moderator was one of these. O. R., Series I, Vol. XXIV, pt. I, 564-566.

${ }^{22}$ By the 29th, McClernand's corps had reached Hard Times. Troops from two divisions (Hovey's and Osterhaus'), and from Burbridge's brigade of A. J. Smith's division, were crowded aboard transports and barges. These soldiers were slated to spearhead the Union amphibious assault on Grand Gulf. Edwin C. Bearss, "Grand Gulf's Role in the Civil War”, Civil War History, V (Iowa City, 1959), 22-23.

${ }^{23}$ The Union ironclads were able to knock out Fort Wade, but they failed to silence the four guns mounted in Fort Cobun. Ibid., 24-25. 
Just at night we went ashore and marched across the point about two miles and camped. The transports ran the blockade in the night. Six men and seven horses were killed while running the blockade on one of the transports. ${ }^{24}$

30th, Thursday. Pleasant. We went on board the boats at nine o'clock and started down the [Mississippi] river. The whole force landed about 15 miles below Grand Gulf, where we went on shore. ${ }^{25}$ Our little army was composed of [Brig. Gen. Peter J.] Osterhaus' division, [Brig. Gen. Alvin P.] Hovey's division, [Brig. Gen. Eugene A.] Carr's division, and [Grig. Gen. Andrew J.] Smith's division and part of some others. $^{26}$ We stayed where we landed till near night when we started on a march again and marched all night. It was tedious although we marched slow and stopped often.

May 1st, Friday. Pleasant. We ended our night's march about sunrise. We stopped, stacked arms, prepared our breakfast, and just as we commenced eating cannonading and musketry commenced. We were ordered in line immediately before we had time to eat our breakfast, and we were marched about $1 / 2$ a mile, and halted and we were ordered to unsling knapsacks. We piled them up in a heap and left them with a guard.

We then started again, went $\frac{1}{2}$ a mile further in a hollow, stacked arms and waited for further orders, which came in a short time for us to meet the enemy, which we did at double quick through a large deep hollow full of cane brakes. We had some pretty hot times. The batteries kept up a brisk firing most of the day, shelling the woods and rebel batteries. With hardly a taste of breakfast and no dinner, and on the move nearly all day, and very warm at that, we had a pretty tough time of it. We fought till nearly dark, when we camped for

${ }^{24}$ According to the "After Action Reports" filed by the naval officers, only one man was killed when the gunboats and transports passed the Grand Gulf batteries on the night of the 29th. Ibid., 27.

${ }^{25}$ Gen. McClernand's XIII Corps landed at Bruinsburg, Miss.

${ }^{26}$ Two divisions of Maj. Gen. James B. McPherson's XVII Corps followed McClernand's troops ashore at Bruinsburg. These two divisions were commanded by Maj. Gen. John A. Logan and Col. John B. Sanborn. O. R., Series I, Vol, XXIV, pt. I, 634, 642-643, 726. 
the night. ${ }^{27}$

Our pickets were fired on once during the night, we were up and in line less than no time, but it did not amount to anything. There were many killed on both sides, and we took quite a number of prisoners. The number of killed and wounded not known yet. ${ }^{28}$

2nd, Sat. Pleasant. We were up early, eat our breakfast, and marched to the battle ground expecting some more hard work, but the Rebs had left in the night. We started on their track, went as far as the town of Port Gibson, when we went in camp, and stayed there all night.

We saw dead Rebels all along the road as we came along. The Rebs crossed Little ... [Bayou Pierre] and burned the bridge after them, so we had to build another before we could cross. ${ }^{29}$ Their loss is estimated to be 3,000 killed, wounded and missing. ${ }^{30}$

${ }^{27}$ The engagement which took place on May 1 is known as the battle of Port Gibson. In this battle, Grant used about 24,000 men and 60 guns. Brig. Gen. John S. Bowen, the Confederate commander, employed about 8,000 soldiers, supported by 16 guns. By this victory, Grant was able to secure his bridgehead east of the Mississippi River.

During the battle of Port Gibson, the 24th Iowa was engaged at two different points. In the morning's action, the Iowan's moved against the position held by Brig. Gen. Martin E. Green's greyclads near Magnolia Church. By 10 a.m., Green's battle line collapsed in the face of the slashing attack delivered by Hoveys and Carr's bluecoated legions. Following Greens retreat, the Federals pushed cautiously ahead.

In the meantime, Gen. Bowen brought up reinforcements. The brigade led by Brig. Gen. William E. Baldwin was posted in the Centers Creek bottom. As the Yankees descended into the hollow, they were fired on by Baldwins troops. Shortly thereafter, Bowen tried to turn the Union left with two of his crack Missouri regiments. Here, the 24th Iowa (along with the other units from Hovey's, Carr's and A. J. Smith's divisions of the XIII Corps, and Burbridge's brigade of the XVII Corps ) was engaged until dusk. At that time, the Confederates retired from the field. Ibid., 602-606, 610-612, 664-666.

${ }^{28}$ In the battle of Port Gibson, the Federals lost 131 killed, 719 wounded, and 25 missing; Gen. Bowen listed his casualties as 68 killed, 380 wounded, and 384 missing. The 24 th Iowa had one man killed and 5 wounded in the day's fighting. Ibid., 583, 585, 668 .

${ }^{29}$ The XVII Corps' pioneer company, assisted by fatigue details from the XIII Corps, built the bridge across Little Bayou Pierre. Lt. Col. James H. Wilson was in charge of the project. Ibid., 128, 638; Thienel, Military Engineer, Nov.-Dec. 1955.

${ }^{30}$ As in all wars, the victors greatly exaggerated the losses of the vanquished. Total Confederate casualties in the battle of Port Gibson were 832 officers and men. O. R., Series I, Vol. XXIV, pt. I, 668. 
Port Gibson is a very pretty place indeed. The boys serenaded the ladies with Union songs. All quiet during the night. We slept sound being somewhat fatigued.

3rd, Sunday. Pleasant. We left Port Gibson in the morning and marched slowly all day. It was hard on me as I was not well. Nice marching only a little dusty. We camped at night about 10 miles from Port Gibson. It is reported that the Rebs are advancing towards us in front. We camped on a bluff. ${ }^{31}$

4th, Monday. Pleasant. We stayed in camp all day. Sent out scouting and foraging parties. I was quite unwell all day. Rainy all night.

5th, Tuesday. Pleasant. We stayed in camp all day. Foraging parties went out foraging. I was sick all day.

6 th, Wed. Pleasant. We started on our march at 4 o'clock in the morning. We marched 8 miles and went in camp at Rocky Springs. ${ }^{32}$ We drew a few rations. We have to forage for the most we have to eat. We get plenty of sugar molasses, smoked and fresh meat, sweet potatoes, etc.

7th, Thursday. Pleasant. Foraging today. About noon orders to march again. We went two miles and camped in line of battle as we expected an attack from the Rebs. ${ }^{33}$ All quiet during the night.

8th, Friday. Pleasant. Stayed in camp all day. Had a general review before Gen. Grant and Hovey. Our camp is on a hill in a sightly place overlooking a considerable part of country. Dress parade in the evening.

${ }^{31}$ Crossing Big Bayou Pierre, the 24th Iowa camped at Willow Springs, O. R., Series I, Vol. XXIV, pt. III, 266; Diary, Raynor (files, V. N. M. P.).

${ }^{32}$ After the Confederates had withdrawn across the Big Black River on May 3, Grant halted his army in the Willow Springs-Hankinson's Ferry area. Here, Grant proposed to await the arrival of Maj. Gen. William T. Sherman's XV Army Corps. Sherman had left Milliken's Bend on the second with two divisions. As soon as Sherman crossed the Mississippi, Grant planned to move against the Southern Railroad of Mississippi.

Learning that Sherman's vanguard was nearing Hard Times, Grant ordered McClernand to begin feeling his way up the Telegraph road. On the 5th, Osterhaus' troops marched from Willow Springs to Rocky Springs; the next day, they were followed by Hovey's troops. O.R., Series I, Vol. XXIV, pt. II, 12, 133; Diary, Ira W. Hunt (files, V. N. M. P ).

${ }^{33}$ The 24th Iowa spent the night of the 7 th on Big Sand Creek. 
9th, Sat. Pleasant. Stayed in camp all day. Most all the boys are washing their shirts as they have only one apiece. I was sick all day. Dress parade in the evening.

10th, Sunday. Pleasant. We started again on the march at 8 o'clock, marched 7 miles then went in camp for the night. $^{34}$ I gave out entirely and had to ride as I could not march any farther.

11th, Monday. Pleasant. I was sick all day. [Major Gen. Frederick] Steele's division passed us today. ${ }^{35}$ The 35th Regiment Iowa passed us today. ${ }^{36}$ Staid [sic] in camp all day.

12th, Tuesday. Pleasant. We started on our march at 4 o'clock. I was not able to march and had to ride. I had a hard time of it. Went 8 miles, had a little skirmish with the Rebs, made them skedaddle. We went into camp. ${ }^{37}$

13th, Wed. Rainy. All the sick that were not able to march were ordered back this morning as they expected a fight soon. Jim Ashton, myself and some others from Co. C, went back about six miles and stopped in a small grove. ${ }^{38}$ It commenced raining hard. We started again at 3 o'clock, went three miles and went in camp. It rained hard. We had to sleep under the wagons.

${ }^{34} \mathrm{Nightfall}$ on the 10th found Osterhaus', Carr's and Hovey's divisions camped on Five-mile Creek. O. R., Series I, Vol. XXIV, pt. I, 595, 616; $O$. R., Series I, Vol. XXIV, pt. II, 12, 31, 41.

${ }^{35}$ In accordance with Grant's instructions, the XIII Corps held its position along Five-mile Creek on the 11th. This was to allow the XV Corps to pass. When he moved against the Southern Railroad of Mississippi, Grant would deploy the XIII Corps on the left, the XV Corps in the center, and the XVII Corps on the right. Gen. Steele commanded a division in Sherman's XV Corps. O. R., Series I, Vol. XXIV, pt. III, 289.

${ }^{36}$ The 35th Iowa was assigned to Brig. Gen. James M. Tuttle's division. Ibid., 253.

${ }^{37}$ Approaching Fourteen-mile Creek, Hovey's division (which was spearheading McClernand's advance) discovered that Whitaker's Ford was guarded by the battle-hardened soldiers of the 1st Missouri Cavalry (dismounted). McGinnis' brigade was promptly deployed and forced the outnumbered greyclads to retire to the right bank of the stream. Hovey directed Col. Slack to send a combat patrol across the creek. Two companies of the 24th Iowa forded Fourteen-mile Creek. On doing so, they were attacked by the Missourians. Outnumbered, the Iowans called for help. The 56th Ohio moved to the Hawkeyes' assistance. After a spirited contest, the Southerners gave way and fell back toward Edwards Station. Diary, W. H. Raynor (files V. N. M. P.); O. R., Series I, Vol. XXIV, pt. II, 40-41, 118.

${ }^{38}$ The sick men undoubtedly spent the night near Old Auburn. 
14th, Thursday. Rainy. We started early on our march. I rode in an ambulance. The roads were very bad. Went ten miles and camped. ${ }^{39}$

15th, Friday. Pleasant. We marched about 10 miles. Sent out scouts all over the country as we expected to be attacked, but we were not. We camped in an open field in line of battle. ${ }^{40}$

16th, Sat. Pleasant. Marched about 10 miles and had one of the hardest battles so far during the war. ${ }^{41}$ The 24 th regiment lost over 200 killed, wounded, and missing. Co. C. lost in killed 6, Captain Johnson, Sergts. [James S.] Carpenter and [Anthony] Mattauch, privates [Joseph P.] Gallino, and [Albert R.] and [William C.] Huey. We had several wounded, two taken prisoners in Co. C. ${ }^{42}$

17th, Sunday. Pleasant. We marched five miles and camped at Edwards Station on the railroad. The name of the late battle ground is called Champion Hill.

${ }^{39}$ Hovey's division camped in the Bakers Creek Bottom, four miles southwest of Clinton. O. R., Series I, Vol. XXIV, pt. II, 41.

${ }^{40}$ The night of the 15th found the Iowans sleeping on their arms in the fields south of Bolton. Ibid.

${ }^{41} \mathrm{On}$ May 16 occurred the battle of Champion, which proved to be the most important in the long, hard Vicksburg campaign. A number of military historians considered Champion Hill the decisive battle of the Civil War.

In a letter to his father dated May 23, Sgt. James H. Lewis of Co. E, 24th Iowa recalled:

May 16th, started at 8\% o'clock and marched till about $10 \%$ when formed in line of battle in an open close by the timber and lay there till $1 \frac{11}{2}$ p.m. when we advanced through the timber into barrens and open fields and our regiment charged on a rebel battery [Waddell's] and took it with severe loss on both sides. We were driving them before us when the 11th Indiana gave way on the right which let the Rebels flank us on the right and we had to retreat. Our regiment went in with 451 men (Co. B was on guard at McClernand's headquarters) and came out with 249 men, losing in killed 38, wounded 132 and 31 missing.

Ltr. James H. Lewis to father, May 23, 1863 (files, V. N. M. P.). According to the "Official Return" filed by Colonel Black, the 24th Iowa lost 35 killed, 120 wounded, and 34 missing in the Battle of Champion Hill. O. R., Series I, Vol. XXIV, pt. II, 57.

${ }^{42}$ Sgts. Carpenter and Mattauch were from Tipton, Pvt. Gallino from Cedar County, and the Huey brothers from Cedar Bluff. These five men had enlisted in Co. C, 24th Iowa in August 1862. Roster and Record of Iowa Soldiers, III, 810, 828, 835, 838. 
18th, Monday. Pleasant. I went back to the hospital to see the boys that were wounded. Found them as well as could be expected. Lieut. [Jeremiah C.] Gue was among the wounded. ${ }^{43} \mathrm{I}$ am much better.

19th, Tuesday. Pleasant. I went back to the regiment. We started again on our march in the afternoon towards Vicksburg. We went across [Big] Black River and camped for the night. Cannonading heard at Vicksburg most all night. ${ }^{44}$ Reported 40,000 rebels in our rear. ${ }^{45}$

20th, Wednesday. Pleasant. We marched back four miles to guard a bridge. We staid [sic] there till near night when we had orders to march to Vicksburg immediately. We marched till 12 o'clock that night. ${ }^{46}$

21st, Thursday. Rainy. We were up early and ordered back to [Big] Black river, where we went into camp. ${ }^{47}$ Foraging parties gone out after provision as we have not much to eat. Pretty hard times.

22nd, Friday. Pleasant. We staid [sic] in camp all day. Co. D went out on picket. Cannonading still going on at

${ }^{43}$ The Union field hospital was at the Champion house. Jeremiah C. Gue, a resident of Tipton, had been commissioned a 1st Lt. in Co. C, 24th Iowa on Aug. 7, 1862. Gue was made a captain on May 17, 1863. Ibid., 828.

${ }^{44} \mathrm{On}$ the afternoon of May 19, Gen. Grant launched his first assault on "Fortress" Vicksburg. This attack was easily repulsed by the Confederates.

${ }^{45}$ There was no truth to the report that 40,000 Rebels were advancing westward from Jackson. At this time, the force which Gen. Joseph E. Johnston was seeking to organize for the relief of Vicksburg mustered about 18,000 strong. O. R., Series I, Vol. XXIV, pt. II, 86, 93; O. R., Series I, Vol. XXIV, pt. III, 901-902, 917.

${ }^{46} \mathrm{Gen}$. McClernand (on the 20th) issued instructions for Gen. Hovey to hurry his division from the Big Black to Vicksburg. McClernand failed to notify Grant of his decision. When Grant learned that Hovey's division was en route to Vicksburg, he exploded. He was afraid that, if the Big Black were left unguarded, Johnston's growing army would come pouring across the unguarded bridges. Staff officers were sent galloping over to McClernand's headquarters with instructions to halt Hovey's march before a disaster occurred. Before McClernand could act, Hovey's troops had reached Durden Creek, where they bivouacked for the night. O. R., Series I, Vol. XXIV, pt. III, 331-332; O. R., Series I, Vol. XXIV, pt. I, 154; Diary, W. H. Raynor (files, V. N. M. P.).

${ }^{47}$ In the meantime, McClernand had prevailed on Grant to allow one of Hovey's brigades to rejoin the XIII Corps before Vicksburg. On the morning of the 21st, McGinnis' troops pushed on to Vicksburg, while Slack's brigade retraced its steps. Ibid. 
Vicksburg. ${ }^{48}$ We drew some hard tack. Very good. My health improving.

23rd, Sat. Cloudy. Still in camp. Cannonading at Vicksburg. Co. I on picket. We had orders to march at 4 o'clock, but did not go. Staid [sic] in camp all night. We expected a regiment of cavalry to relieve us but they did not come.

24th, Sunday. Pleasant. We had orders to march at 10 o'clock. We started at that time and marched 14 miles and camped in the rear of Vicksburg. ${ }^{49}$ I was sick and had to ride as I could not march. We camped in a valley in the woods all night. ${ }^{50}$

25th, Monday. Pleasant. Our brigade was ordered up near the breastworks to support the batteries with two days rations. The sick and wounded were left in camp. Cannonading all day. Our boys lay in the rifle pits and pop at the Rebs every time they show themselves above the forts. ${ }^{51}$

26th, Tuesday. Pleasant. Still picking away at the Rebs, they don't reply much. One of their magazines was blown up today.

27th, Wed. Pleasant. Our brigade was relieved this morning by the first [McGinnis']. Still pecking away at the forts.

28th, Thursday. Pleasant. Still shooting away at the Rebel forts. They reply back but very little. Saving their ammunition.

29th, Friday. Rainy. The 2nd brigade [Slack's] went out on picket to support the batteries, and relieved the 1st brigade. Co. $\mathrm{H}$ had one man wounded by a shell from our

${ }^{48}$ On the $22 \mathrm{nd}$, the Army of the Tennessee assailed the earthworks guarding the approaches to Vicksburg for a second time. The Confederate defenders again checked the Union onslaught. At nightfall, the bluecoats fell back, having lost 3,199 officers and men. O. R., Series I, Vol. XXIV, pt. II, 165.

${ }^{49}$ Before leaving for Vicksburg, Slack's brigade was relieved of the responsibility for guarding the Big Black Bridge by a force commanded by Gen. Osterhaus. Ibid., 21, 209; Diary, W. H. Raynor (files, V. N. M. P.).

${ }^{50}$ Reaching Vicksburg, the soldiers of the 24th Iowa camped in the Durden Creek bottom.

${ }^{51}$ When they moved to the front, the soldiers of the 24th Iowa occupied the rifle pits on a spur 350 yards east of Square Fort. Topographical Map of Vicksburg National Military Park, Prepared under the direction of the Hon. Elihu Root, Secretary of War, by the Vicksburg National Park Committee, 1903. 
own guns. Still bombarding the forts. The gunboats are shelling occasionally.

30th, Sat. Pleasant. Our boys still behind the breastworks popping away at the rebs. Heavy cannonading most all night. Our wounded at Champion Hill are parolled prisoners. A force of rebs came there and made them prisoners and parolled them. ${ }^{52}$

31st, Sunday. Pleasant. Our brigade was relieved and went to camp about 10 o'clock. Not much firing today. I built me a bunk out of long canes. It makes a very comfortable bed to sleep on. Our camp is in a pleasant place in a valley in the woods. $^{53}$

June 1st, Monday. Pleasant. We stayed in camp all day. At 12 o'clock at night we were ordered in line of battle, as we expected a charge from the rebs on our left. They did not come, however, and we went back to bed and were not alarmed again that night.

2nd, Tuesday. Pleasant. We went out to the rifle pits and popped away at the Rebs. We have a nice place in a hollow below the rifle pits to stay when not on duty. Rebel balls come close sometimes.

3rd, Wed. Pleasant. Still in the pits. One company goes in the pits for two hours then are relieved by another com-

${ }^{52} \mathrm{~A}$ Confederate cavalry patrol slipped through the line of outposts manned by the 6th Missouri Cavalry and captured and paroled the Union wounded confined in the field hospitals in the Champion Hill area. O. R., Series I, Vol. XXIV, pt. II, 211-212.

${ }^{53}$ Sgt. Lewis, in a letter to his father, described the type of beds built by the Iowans:

We had got shades built . . . [here] same as we build cattle sheds in Iowa, that is by setting crotches and covering with boughs of trees but leave it open at the sides and ends so that the air can get through. We had also got our beds raised from the ground by setting crotches and laying poles in them for the ends and then we cut and carried cane (such as some have for fish poles [in the] north) and put on the poles and then get corn husks or corn leaves for bedding. It makes a bully bed for the cane springs just enough to lay easy. We tied our cane up and got it hauled. I also tied my husks in my blanket and got them hauled too. I had just got some boards and made a table and have got it up here too and have built another shade over our bunk this forenoon which keeps the dew off at night as well as the sun by day.

Ltr., Lewis to father, June 4, 1863 (files, V. N. M. P.). 
pany, so change around. I mean each regiment does the same thing.

4th, Thursday. Pleasant. We were relieved at 10 o'clock and went in camp in the afternoon. Gov. [Samuel J.] Kirkwood, Adjt. Gen. [Nathaniel B.] Baker and some others made some short speeches to the 24 th regiment. ${ }^{54}$ Just at night we we had orders to move. We went about $1 / 2$ mile up the valley and went in camp. This is not as good as the one we left. ${ }^{55}$

5th, Friday. Pleasant. Cos. $\mathrm{C}$ and $\mathrm{H}$ went out in pits at 3 o'clock in the morning, as we dare not go by daylight. Cannonading brisk today. We stayed in the pits all night as no relief came.

6th, Sat. Pleasant. Henry Clark came down to see us. We went about two miles with him when he went back to his regiment. Cannonading still goes on.

7th, Sunday. Pleasant. Had a sermon by our new chaplain. ${ }^{56}$ A squad detailed to dig rifle pits in the night.

8th, Monday. Pleasant. We stayed in camp all day. My health is getting better all the time.

9 th, Tuesday. Pleasant. The 24th regiment went out in the rifle pits. I carried the flag. I had no gun.

\footnotetext{
${ }^{54}$ Sergeant Lewis wrote of the visit of Governor Kirkwood's party to the encampment of the 24th Iowa:

Well, I didn't write any yesterday afternoon as I didn't

feel well and we got orders to be ready to march at a moment's notice; then after we packed up Gov. Kirkwood, Adjutant General Baker, and Senator [James F.] Wilson spoke to our regiment. Surgeon Gen. Hughes was along. They came down with sanitary stores from Iowa and were looking after the Iowa troops. ... Ibid.
}

${ }^{55}$ The campground occupied by the 24th Iowa from June 4 to the end of the siege was in a ravine about 1,000 yards southeast of Square Fort. Topographical Map of the Vicksburg National Military Park (files, V. N. M. P.).

${ }^{56}$ In a letter dated the 8 th, Sergeant Lewis casts additional light on the church services:

We had preaching in our regiment yesterday by our Chaplain and while he was preaching a minie ball came buzzthrough the only open space in the assembly and struck the ground just at the farther side of him [the chaplain] but did not hit anyone. These messages come occasionally from the Rebs and light in our camp, but much oftener in the 28th [Iowa], as they are nearer to the battery that the Rebs are firing at.

Ltr., Lewis to father, June 8, 1863 (files, V. N. M. P.). 
10th, Wed. Rainy. We were relieved this morning. Had a very hard rain. It flooded our camp as we were in a hollow on low ground. A good many sick in our regiment. ${ }^{57}$

11th, Thursday. Pleasant. Some of our things came up from the river that we left at Milliken's Bend when we started on our march. The rebel balls come in our camp rather thicker than is agreeable sometimes. Some of the boys have been wounded.

12th, Friday. Pleasant. The 24th regiment stayed in camp all day. Homer Curtis and myself took a long stroll through the woods and over the hills. ${ }^{58}$ Tom Faucett came to the reg-

${ }^{57}$ Sgt. Lewis, in a letter to his father dated June 11, tells of the heavy rainfall and the arduous duty in the trenches:

Our regiment went into the rifle pits Tuesday. Our company went into the pit nearest the rebels' fort. It was about 200 yards from the Rebs. [On June 4, the soldiers of the 24th Iowa had thrown up and occupied a line of rifle pits on a spur 200 yards east of Square Fort.] We were divided in two reliefs, the first went in at three in the morning and stayed all day, the others went in about 8 p.m. and stayed till three. I was in the second relief and was up till 12 then slept till three. It is a rather dangerous pit to get to in the day light. ... W We came out all right.

Well, we came into camp about 4 o'clock and I spent about an hour and Laffe waked me up and said it was going to rain so I got up and fixed up my oil poncho to keep the bed dry and he had breakfast ready. So we ate breakfast. It began raining before I got the blankets quite fixed and just poured down till about 8 o'clock.

Soon after I was done breakfast I was detailed to go on picket. So down came the poncho and I took a day's ration of hard tack, and gun, and accoutrements and started. . . . Before I got away the little creek that we are camped on was out of the banks and water was knee deep around our bunk and many were worse off than we were, but you may imagine what a nice time we had wading out through the water and mud knee deep, had to go about three miles. Rained most of the time till 2 p.m. and then didn't rain any more till after seven and it rained till about nine. I carried some rails to lay on and made a little tent over them with my poncho, having it slope each way like the roof of a house and slept quite dry. ... .

Ltr., Lewis to father, June 11, 1863 (files, V. N. M. P.); Topographical Map of the Vicksburg National Military Park.

${ }^{58} \mathrm{~A}$ resident of Cedar County, Homer A. Curtis enlisted in Co. C on Aug. 11, 1862. Roster and Record of Iowa Soldiers, III, 810. 
iment a parolled prisoner. ${ }^{59}$ Our wounded doing well, going up the river. One of Co. F's men was shot while in his bunk by a rebel ball.

13th, Sat. Pleasant. The 24th regiment went out in the rifle pits to relieve the 56 th Ohio.

14th, Sunday. Pleasant. Capt. [Stephen H.] Henderson preached a good sermon in camp this morning. ${ }^{60}$ The Rebs attempted to make a charge today, but were driven back in the forts by our men. Lively times for awhile. Our batteries poured grape and cannister [sic] in them pretty lively.

15th, Monday. Pleasant. Sharpshooting all along the line on both sides, shell and ball. The balls came thick in our camp. We had to move our quarters over on the side hill so as to not to be so much exposed. One of Co. F's men was shot in the leg while in his tent.

16th, Tuesday. Rainy. Joe Downing and John Collumber went up the river. ${ }^{61}$ We put up our shanties this forenoon. The big guns are shooting steady today. Some wounded in our brigade today. None from the 24 th regiment.

17th, Wed. Pleasant. The 24th [Iowa] went in the rifle pits. The rebel bullets came thick over our heads. Not in the pits. The rebs opened some of their big guns on us. We were in the pits all night.

18th, Thursday. Pleasant. We were relieved by the 47th Indiana. ${ }^{62}$ Frank Barrett of the 20th Iowa came up to see us. ${ }^{63}$ In the night the rebel pickets and our pickets had some pretty sharp shooting. It caused some excitement and nearly all the regiments were up in line in a hurry.

\footnotetext{
${ }^{59}$ Thomas B. Fawcett of Cedar County had enlisted in Co. C, 24th Iowa on Aug. 11, 1862. Ibid., 825.

${ }^{60}$ Stephen H. Henderson of Sabula had been commissioned captain on Aug. 7, 1862, and placed in command of Co. A, 24th Iowa. Ibid., 823.

${ }^{61} \mathrm{John}$ Collumber was from Cedar County, while Joseph B. Downing called Mechanicsville his home. Both men had enlisted in Co. C, 24th Iowa in August, 1862. Ibid., 810, 819.

${ }^{62}$ The 47 th Indiana was one of the three other regiments assigned to Slack's brigade. O. R., Series I, Vol. XXIV, pt. II, 151.

${ }^{63}$ James F. Barrett of Inland had enlisted in Co, C, 20th Iowa on Aug. 6, 1862. Barrett died at Vicksburg on July 10, 1863. The 20th Iowa was assigned to Maj. Gen. Francis J. Herron's division. At this time, the 20th Iowa was posted in the Warrenton road sector. Roster and Record of Iowa Soldiers, III, 355; O. R., Series I, Vol. XXIV, pt. II, $158,318-319$.
} 
19th, Friday. Pleasant. The batteries are putting it right to the rebels today. I was quite unwell all day.

20th, Sat. Pleasant. All the big guns clear around the line commenced firing at 4 o'clock in the morning. They had orders to fire 4 hours in succession. ${ }^{64}$ They made some music. We were ordered out in line of batle as we expected a charge from the rebels.

21st, Sunday. Pleasant. The 24th [Iowa] went out in the pits. Not much shooting by the artillery, but the infantry on both sides kept up a brisk fire all day. I stayed in camp.

22nd, Monday. Pleasant. Our boys were relieved a little after sunrise and marched in camp. Reported that [General Joseph E.] Johnston and Osterhaus are fighting on Black River. They have sent in here for reinforcements. ${ }^{65}$ Our pickets were doubled on the outside line. Not much shooting today from the forts.

23rd, Tuesday. Pleasant. I was quite unwell. Not much firing today. The pickets were doubled. Extra fatigue men. Raining.

24th, Wed. Rainy. Johnston reported this side of [Big] Black River. ${ }^{66}$ I was sick all day and night.

25th, Thursday. Pleasant. The 24th went in pits. Our

\footnotetext{
${ }^{64}$ In accordance with Grant's orders, all the artillery pieces which the Union cannoneers had mounted on the investment lines opened fire at 4 a. m. Official Records of the Union and Confederate Navies in the War of the Rebellion, Series I, Vol. 25, pp. 83-85. (Cited hereafter as O.R.N.)

${ }^{65}$ On June 22, a fast-moving Confederate column advanced down the "Mechanicsburg Corridor" and defeated a detachment of the 4th Iowa Cavalry at Hill's plantation. Following this clash, a report reached Grant's headquarters that Johnston's Army of Relief had crossed the Big Black. Reacting to this news with his customary vigor, Grant organized a special command. Gen. Sherman was placed in charge of this force and given the mission of opposing Johnston's advance. The report that Johnston had crossed the Big Black and was in contact with Osterhaus' troops was without foundation. O. R., Series I, Vol. XXIV, pt. II, 509-12. O. R. Series I, Vol. XXIV, pt. III, 427-428.

${ }^{86}$ There was no substance to the rumor that Johnston's Army was across the Big Black. At this time, two of Johnston's infantry divisions were at Vernon, one near Livingston, and the fourth at Jackson. Confederate Letters of John W. Hogan, Bell T. Wiley, ed. (Athens, 1954), 20; O. R., Series I, Vol. XXIV, pt. III, 971.
} 
guns blew up a Rebel battery, made a charge and took a fort. ${ }^{87}$ Lively times.

26th, Friday. Pleasant. We were relieved by the 87 th Illinois. ${ }^{68}$ Said regiment just attached to the 2 nd brigade. We drew rations and clothing. ${ }^{69}$

27th, Sat. Pleasant. We drew some clothing. I drew a pair of pants, rubber blanket. Nothing of importance going on.

28th, Sunday. Pleasant. Not much firing today. Preaching in camp by Chaplain [John T.] Simmons of the 28th [Iowa]. ${ }^{70}$ Co. $\mathrm{B}$ returned to the regiment. ${ }^{71}$

29th, Monday. Pleasant. Had some sharpshooting on both sides today. The rebs threw shell and ball over our camp rather saucy. We signed the pay roll today.

30th, Tuesday. Pleasant. We were mustered for pay in the morning. The 24 th went in the rifle pits. Then Co. C came back and went out in the night as front pickets, close to the fort. I stayed in camp to take care of Jim Ashton. He was quite sick.

July 1st, Wed. Pleasant. We drew rations. Capt. Gue

${ }^{67} \mathrm{~A}$ mine was detonated under the 3d Louisiana Redan on June 25. Following the explosion of the mine, the Federals launched an attack aimed at gaining possession of the 3d Louisiana Redan. After much bitter fighting, the Federals were thrown back. Andrew Hickenlooper, "The Vicksburg Mine", Battles and Leaders of the Civil War, III, 539542.

${ }^{68}$ The 87th Illinois was assigned to Slack's brigade on June 23. Prior to joining Slack's command, the Illinois regiment had been stationed at Warrenton. Report of the Adjutant General of the State of Illinois, Vol. V (Springfield, 1886), 239.

${ }^{69}$ In a letter to his father dated June 28, Sgt. Lewis told of the prices which the soldiers paid the sutlers for choice tidbits to supplement their rations:

I have just got the dinner dishes washed, had fresh beef, summer squash (with 50 cent butter on it) and boiled corn, hard tack, mustard, peppers, etc. I tell you the squash and boiled corn makes one think of old times when butter was only selling for 8 to 10 cents per pound instead of 50 cents.

Dried apples are 20 and 25 cents per pound. Dried peaches 25 , cheese 50 , etc., etc.

Ltr., Lewis to father, June 28, 1863 (files, V. N. M. P.).

${ }^{70} \mathrm{John}$ T. Simmons of Marengo had been commissioned a captain and appointed chaplain of the 28th Iowa on Sept. 16, 1862. Roster and Record of Iowa Soldiers, III, 1243.

${ }^{71} \mathrm{Co}$. B had been on duty at corps headquarters. 
made out the monthly returns. I was promoted to Sergeant. Three o'clock we were ordered to get all our accoutrements on and be ready at a moment warning. We were not called out till 12 o'clock that night, when we were ordered in line and marched out two miles in the rear, as the pickets had been driven in by rebel cavalry. We stayed there till morning. ${ }^{72}$

2nd, Thursday. Pleasant. [Lt.] Colonel [John Q.] Wilds marched us back to camp to get our breakfast. ${ }^{73}$ We stayed in camp one and one-half hour then took one days rations and marched back as a reserve for the pickets. It was very hot but we got in a grove where it was very comfortable. We were relieved at dark and went back to camp, eat our suppers and went to bed. At 11 o'clock that night we were ordered in line and kept there about an hour waiting for further orders, when we were ordered to our quarters. The cause of the alarm was the rebels firing on our pickets from the forts. They killed one man and wounded three more.

3rd, Friday. Pleasant. We drew four months pay up to the first of July. Most of the boys sending money home. The Rebs sent out a flag of truce. ${ }^{74}$ Firing commenced again in the

${ }^{72}$ On July 1, a detchment from the 15 th Illinois Cavalry had clashed with a Confederate patrol near Hankinson's Ferry. The bluecoated horsemen had been forced to retire across the Big Black. Despite Sherman's reports discounting a Rebel movement south of the Southern Railroad of Mississippi, Grant played it safe. The next day (the 2d), Brig. Gen. Michael K. Lawler's brigade was sent to Hankinson's Ferry and found that the report of a Confederate concentration in that area was unfounded. O. R., Series I, Vol. XXIV, pt. II, 248-249; O. R., Series I, Vol. XXIV, pt. I, 113.

${ }^{73} \mathrm{Col}$. Byam had resigned his commission on June 30 . Upon the colonel's departure, Lt. Col. John Q. Wilds took charge of the regiment. A resident of Mt. Vernon, Wilds had been appointed lieutenant colonel on Aug. 10, 1862. Roster and Record of Iowa Soldiers, III, 795.

${ }^{74} \mathrm{Gen}$. Bowen appeared on the Boldwin's Ferry road about 10 o'clock with a flag of truce. While Bowen was laying the groundwork for an afternoon meeting between Gens. Grant and Pemberton, hostilities were suspended along the sector of the front held by the XIII Corps. When Bowen returned to the Confederate lines, the fighting was resumed.

A little after 3 p.m., Grant and Pemberton met near the Jackson road to talk over terms for the possible surrender of Vicksburg. Nothing came of this meeting except a decision to continue negotiations. Before parting, the two officers agreed that hostilities should be suspended and not renewed unless negotiations were broken off. Ulysses S. Grant, Personal Memoirs of U. S. Grant, Vol. I, (New York, 1885), 465-466; Ltr. B. J. Williams to W. T. Rigby, June 30, 1905 (files, V. N. M. P.). 
afternoon. Firing ceased at four o'clock-perfectly quiet all night.

4th, Sat. Pleasant. Hurrah for Vicksburg and the 4th of July! The rebs surrendered Vicksburg to Gen. Grant at 8 o'clock in the morning. We had orders to be ready to march at a moments warning. ${ }^{75}$ Fire works in the evening. Jim Howard came in the evening. ${ }^{76}$ We expected to leave in the evening but did not. ${ }^{77}$

${ }_{75}$ Gen. Grant planned to reinforce Sherman's force, which was guarding the eastern approaches to Vicksburg, with the XIII and XV Corps. Following the arrival of these units, Sherman would attack the army which Johnston had assembled in his unsuccessful effort to relieve Vicksburg. O. R., Series I, Vol. XXIV, pt. III, 470. Most sources give the time of the Confederate surrender as 10 a.m.

${ }^{76} \mathrm{~A}$ resident of Tipton, James D. Howard had enlisted in Co. C, 24th Iowa on Aug. 8, 1862. Roster and Record of Iowa Soldiers, III, 835. To celebrate the fall of Vicksburg, Sgt. Lewis treated himself to an oyster dinner. Ltr., Lewis to father, July 4, 1863 (files, V. N. M. P.).

${ }^{77}$ The XIII Corps started for the Big Black on the morning of the 5th. O. R. Series I, Vol. XXIV, pt. II, 574, 591, 597, 603, 609.

\section{BOOK REVIEWS}

A Pictorial History of the Civil War Years, by Paul M. Angle, was also recently released by Doubleday \& Company, Inc. This book contains over 350 photographs and sketches of the Civil War. Many of the pictures included in this excellent collection have never before been published. The editorial material is brief but thorough and the book is certainly worth the $\$ 6.95$ for which it sells.

The author of A Pictorial History of the Civil War Years is director of the Chicago Historical Society and a directing member of the American Historical Association. Some of his other published books include: Lincoln, 1854-1861; The Living Lincoln and Tragic Years, 1860-1865 (with Earl Schenck Miers); The American Reader and Crossroads, 1913.

The American Presidents, by David C. Whitney, tells the stories of the 35 men who have served as leaders of our country. Extremely informative and well written, this book not only gives biographical data but also gives insight into the political ideals, campaigns and careers of our Presidents.

The author is the editor of the Education Division of Cowles Communications, Inc., in New York. He is a past Managing Editor of the World Book Encyclopedia, Chicago, and a past mayor of Deerfield, Ill. In 1964, Mr. Whitney wrote Signers of the Declaration of Independence and in 1965, Signers of the Constitution. These two books, as The American Presidents, were published by Doubleday \& Company, Inc.

The American Presidents sells for \$5.95. For additional information, write Doubleday \& Company, Inc., 277 Park Avenue, New York, N. Y. 10017. 
Copyright of Annals of Iowa is the property of State of Iowa, by \& through the State Historical Society of Iowa and its content may not be copied or emailed to multiple sites or posted to a listserv without the copyright holder's express written permission. However, users may print, download, or email articles for individual use. 